Marquette University

e-Publications@Marquette

Theology Faculty Research and Publications

Theology, Department of

$12-1-2018$

\title{
On Pediatric Vaccines and Catholic Social Teaching
}

Conor M. Kelly

Marquette University, conor.kelly@marquette.edu

Accepted version. Horizons, Vol. 45, No. 2 (December, 2018): 287-316. DOI. (C) 2018 Cambridge University Press. Used with permission. 


\title{
Marquette University
}

\section{e-Publications@Marquette}

\section{Theology Faculty Research and Publications/College of Arts and Sciences}

This paper is NOT THE PUBLISHED VERSION; but the author's final, peer-reviewed manuscript. The published version may be accessed by following the link in the citation below.

Horizons, Vol. 45, No. 2 (December, 2018): 287-316. DOI. This article is (C Cambridge University Press and permission has been granted for this version to appear in e-Publications@Marquette. Cambridge University Press does not grant permission for this article to be further copied/distributed or hosted elsewhere without the express permission from Cambridge University Press.

\section{On Pediatric Vaccines and Catholic Social Teaching}

Conor M. Kelly

\begin{abstract}
Determining whether, and when, to get one's children vaccinated has become an increasingly controversial decision, often leaving parents fearful of making the "wrong" choice. Part of the challenge stems from the fact that what is rationally optimal for an individual is inherently at odds with the best outcome for the community, meaning that if everyone acted out of self-interest with respect to pediatric vaccines, communal health would suffer significantly. Given these tensions, the issue of pediatric vaccines benefits greatly from the nuanced assessment of Catholic social teaching. Specifically, the Pontifical Council for Justice and Peace's "four permanent principles" of human dignity, the common good, subsidiarity, and solidarity highlight the issues involved and help parents navigate this significant medical choice with a more informed conscience and a greater sense of their moral responsibilities. The end result is a fruitful alignment between Catholic social teaching and ethics in ordinary life.

One of the most common laments in many Catholic theological circles revolves around the relative invisibility of Catholic social teaching among the faithful. Undeniably, part of the problem stems from the fact that Catholic social teaching is disassociated from everyday life for most Catholics. As Kelly Johnson argues, "The teaching needs to be more clearly integrated into the ordinary life of faith" if it is ever going to live up to its
\end{abstract}


potential. 1 One of the best ways to do this is to demonstrate the viability of Catholic social teaching's specific principles for everyday ethical discernment. To that end, this article considers the implications of Catholic social teaching for pediatric vaccines. $\stackrel{2}{ }$ While this may seem like a trivial matter, the truth is that much is at stake in this question, for both the moral agents involved and the larger theological tradition. First, as a result of an increasingly aggressive anti-vaccination movement in the United States, parents are often uncertain about what is truly the right thing to do for their children. Catholic social teaching has the resources to help parents navigate this uncertainty, reframing moral obligations in a way that serves the common good and alleviates doubt. Second, despite the fact that health care confronts people with some of the most self-consciously moral decisions of their lives (there are ethics committees standing by or on call at virtually every hospital in the United States, after all), most Catholics find few resources to evaluate these decisions with the fullness of their faith. What is especially absent is the church's social tradition, for even in Catholic contexts, "a procedural bioethics that reduce[s] all substantive moral values to autonomy and informed consent" tends to prevail, largely because theologians have failed to challenge a field "governed by the values of individualism, science, technology, the market, and profit" in an effective fashion. ${ }^{3}$ To the extent that Catholic social teaching can say something substantive about the concrete case of pediatric vaccines, then, it has the chance to break down some of the barriers still separating Catholic bioethics from Catholic social ethics, yielding a boon for both fields. The practical result of this mutual engagement is a distinctively Catholic approach to the issue of pediatric vaccines that moves parents away from a reliance on a narrow view of autonomy and a strictly utilitarian calculus to a sense of moral responsibility that befits the dignity of the human person created in the image of a relational God.

\section{The Normative Debate about Pediatric Vaccines}

In order for Catholic social teaching to have a real impact on the question of vaccines, its theological analysis must begin with an awareness of the concrete realities that currently define this issue. Broadly, the main normative question that parents must face when considering pediatric vaccines is whether or not their children should get each of the vaccines that the American Academy of Pediatrics recommends for all children. If the answer is yes, then parents also face another normative debate about whether or not those vaccines should be administered according to the recommended schedule, or if a child should follow a delayed schedule that further spaces out the doses. While facing these decisions is routine now, this was not always the case. In fact, barely more than a generation ago, the promise of vaccines so heavily outweighed the gloomy prospects of the diseases they managed to prevent that most parents regarded vaccination as a foregone conclusion. ${ }^{4}$ Effectively aiding parents today therefore requires attending to the unique contours of the current normative debate about pediatric vaccines, and this, in turn, requires appreciating the larger historical context from which the contemporary discussion has emerged.

Historically, vaccines have been an ethically fraught issue, and public opinion on the appropriateness of vaccination has ebbed and flowed over time. The basic principle of vaccination, which involves introducing infectious agents into otherwise healthy human beings in order to stimulate an immune response that will then protect against more serious future infections, is fairly counterintuitive, especially on a theoretical level. Unsurprisingly, many observers balked at the strategy when it was first introduced. ${ }^{5}$ Today, the theoretical principle is not as often in dispute, but ethical issues related to the development of vaccines persist. Research ethics are a particular concern because clinical trials require testing as-yet unproven vaccines in order to determine their effectiveness. While this is a typical ethical challenge for all clinical trials, vaccine trials press the ethical questions in more profound ways because vaccine trials start with already healthy individuals and offer the prospect of only long-term benefits, not immediate results. ${ }^{-}$In addition, the actual process of vaccine production has also been subject to ethical criticism, as a number of vaccines have been built around cell lines of dubious provenance, from the use of the infamous HeLa cells in the development of Jonas Salk's polio vaccine to 
the construction of some vaccines from cell lines derived from aborted fetuses. ${ }^{?}$ Nonetheless, the primary source of the current normative debate about pediatric vaccines revolves around a separate issue: individual autonomy and the burden of the risks associated with vaccination.

In a certain sense, it is not surprising that the issue of autonomy is the locus of the contemporary debate about pediatric vaccines, because autonomy has become an increasingly central feature of the bioethics landscape in the United States. Although initially couched as a subsidiary form of the principle of respect for persons, autonomy has since taken on a more libertarian connotation and assumed a default priority above all other bioethical principles, at least in the US context. ${ }^{8}$ Current debates about pediatric vaccines simply reflect the extension of this autonomy ethic into the sphere of preventative care, where disputes revolve around the issue of who should decide whether and when children receive a recommended vaccine.

The perceived problem arises because public health authorities in the United States have developed a recommended schedule for the administration of the first dose of ten vaccines during a child's first eighteen months. ${ }^{9}$ This schedule has been designed for greatest efficacy-both from the perspective of the patient's immune response and from the perspective of public health-so state governments routinely incorporate these recommendations into their requirements for public (and sometimes private) school admission. ${ }^{10}$ In an environment that idolizes autonomy as the gold standard for medical ethics, some challenge these compulsory laws and the recommended schedule on which they are based as unethical violations of patient autonomy. This has been especially true in recent years as the number of recommended vaccines has increased and as a series of questions has emerged about the possibilities of long-term side effects from various vaccines. $\underline{11}$ Indeed, the current normative dispute about pediatric vaccines essentially reflects a desire to reassert parents' autonomy for their children's health care, with a growing number of parents insisting that they should be able to decide what risks their children need to face, precisely because these parents have come to believe that external authorities are not assessing those risks adequately enough. As a result, the number of children without medical contraindications who nonetheless enter school without the required vaccines doubled between 1991 and 2004, and by 2008 the number of parents choosing to refuse or delay one or more vaccines in the recommended schedule for any reason had reached roughly 40 percent. $\underline{12}$ Recent research from one private health insurance company suggests trends have shifted slightly, but nearly one-quarter of the children insured by the company were still not fully vaccinated at age three in $2016 . \underline{13}$

The current resistance to the recommended vaccination schedules is not simply rooted in the increasing priority of autonomy in medical ethics, though. Reports of adverse side effects of vaccines have also played a major role in prompting parents to assert their autonomy in this particular way. The first of these reports appeared in the United States in the early 1980s, as a TV documentary described an anecdotal link between the combined DTP vaccine (diphtheria, tetanus, and pertussis) and severe seizures, epilepsy, and even long-term brain damage. $\underline{14}$ The documentary sparked national outrage, spurring an increase in refusals of the DTP vaccine and even other vaccines as well. The association between these conditions and the DTP vaccine was eventually disproved, but the seeds of doubt and distrust had been sown. $\frac{15}{15}$ The stage was therefore set for an even stronger reaction to a subsequent media blitz about long-term risks from vaccines in the late 1990s that focused on a link between the measles, mumps, and rubella (MMR) vaccine and autism. Although connections between vaccines and autism had been suggested before, a 1998 study published in The Lancet proposed a theoretical explanation for the development of autism based on the MMR vaccine in particular. $\underline{16}$ Like the DTP scare, this link was also refuted by further scientific evidence, but once again doubts persisted, and many of the people who had heard of the initial 1998 study had never heard that it was later discredited. $\underline{17}$ In the United States, concerns about the MMR vaccine causing autism combined with ongoing worries about some of the chemical preservatives used in vaccines-especially Thimerosal, an additive containing mercury-to generate a persistent link between autism and vaccines in the minds of many parents and in certain areas of the public discourse. $\underline{\underline{18}}$ 
The best scientific evidence to date indicates that the most common anxieties about vaccines are not supported by the data, but that does not mean that parental concerns are entirely unmerited. While the specific claims that typically generate parents' resistance to recommended vaccine schedules are unfounded, more general qualms about the risks associated with vaccines are not altogether unwarranted. After all, vaccines are a medical intervention, and, like all medical interventions, they carry some level of inherent risk. First, vaccines introduce the basic risk of upsetting the status quo because they involve doing something to an already healthy individual. This is what one might call the intuitive risk of vaccines, and it was the initial concern that plagued the work of the earliest vaccine pioneers. Today, many of these intuitive risks have been reduced by standardizing the procedures for administering vaccines and by increasing the stringency of safety requirements used in the research and development phases of vaccine production. $\underline{\underline{19}}$ Nevertheless, the basic risk of somehow upsetting a currently healthy individual is never zero.

Second, there are also specific risks, because each vaccine carries its own distinct set of potential side effects. For example, many pediatric vaccines are associated with relatively mild side effects, like low-grade fevers, pain at the site of the shot, or other forms of physical discomfort. Some of these milder side effects were very common in older vaccines, but new formulations have reduced the frequency and duration of these mild side effects, and most parents manage these effectively. More significantly, pediatric vaccines also have the potential to induce some serious side effects. Some vaccines can cause seizures, others can cause pneumonia, and some have been associated with extreme problems like deafness and permanent brain damage. However, these worst-case scenarios have not been conclusively linked to the vaccines. $\underline{\underline{20}}$ While these conditions are all severe, the risk of any one child experiencing one or more of these serious side effects is extremely low-the most common, seizures related to high fevers, are reported in less than one-third of 1 percent of children who receive

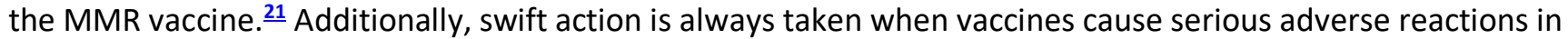
anything more than a few isolated instances. (A good example is the first vaccine against rotavirus, a gastrointestinal illness, when increased cases of intussusception-a potentially life-threatening blockage of the intestine-were reported in patients who had received the vaccine. The US government investigated and determined that the vaccine did increase the risk of this dangerous condition, so the vaccine was immediately removed from the market. $)^{\underline{22}}$ Beyond these specific side effects, there is also the possibility of severe allergic reactions to a vaccine itself, or to one of its components. The possibility of an allergic reaction is hard to predict, but as with other documented health risks connected to vaccines, the overall numbers for allergic reactions are also low, typically fewer than one in one million. $\underline{23}$ Still, none of these risks ever disappears entirely, and an individual's past experience with negative side effects tends to correlate with his or her risk for future complications, especially in the case of allergic reactions. As a result, the aggregate risk for one child is exceptionally low from a statistical point of view, but the actual risk for an individual will vary, to the point that some children may not be able to receive one or more of the recommended vaccines at all because the specific risks for a given child are unacceptably high. $\underline{\underline{24}}$

Parents, then, have every right and every reason to consider these risks as they make decisions about their children's health. In keeping with the standard bioethical principle of informed consent, parents need to think about all of these side effects, even if they represent the least likely, worst-case scenarios because, at the end of the day, no vaccine is 100 percent risk-free. As two of the staunchest proponents of the standard vaccine schedule, pediatricians Paul Offit and Louis Bell, state, "If you define safe as completely free of any possible negative effects, then the answer is no [vaccines are not 'safe']. But nothing is completely safe.... The better question is, 'Do the benefits of vaccines (avoiding infections) outweigh their risks (side effects)?'”25 Given that vaccines are administered to already healthy children, the risk of serious side effects and severe allergic reactions might seem unjustified because the gravity of these problems is so significant even if their quantity is so low. In some instances, this may be true, especially for children who have medical conditions or previous experiences with vaccines that serve as medical contraindications for additional immunizations. In most cases, 
though, the assessment of risk is a little more complicated because the question is not simply about subjecting a healthy child to possible side effects; it is really about subjecting a healthy child to possible side effects in order to keep that child healthy in the future. The real point of comparison for the risk assessment, then, is not the currently healthy child, but the consequences for that child if he or she actually contracted the disease that a particular vaccine is designed to prevent. From this perspective, the rewards tend to outweigh the risks quite significantly.

Consider first the most famous pediatric vaccine, Salk's polio vaccine. While most people in the United States today are unfamiliar with polio (in large part because of the success of vaccinations), the disease took a serious toll before Salk introduced his successful vaccine in 1955. Previously, polio epidemics were a yearly occurrence, known as "polio season." The worst polio season was in 1952, when the virus left 57,000 people stricken, 21,000 paralyzed, and 3,000 dead. $\frac{\mathbf{2 6}}{}$ The disease therefore carried serious symptoms in serious numbersapproximately one in every one hundred cases resulted in paralysis-so the risks associated with this disease are high; meanwhile, the risks of serious side effects from the current vaccine are nonexistent, so there is an easy case to make for the polio vaccine. $\underline{27}$

The same can also be said for rubella, one of the diseases countered by the MMR vaccine, which was linked to the since-discredited autism controversy in the late 1990s. Before effective vaccines were introduced, rubella caused serious birth defects, leaving upward of 20,000 babies blind, deaf, or brain-damaged every year. $\underline{\mathbf{2 8}}$ Based on birth statistics for 1960, the year before the polio vaccine became commercially available, the population risk of birth defects from the disease was 0.47 percent, or approximately 1 in 212 children, before vaccination became a common public health practice. $\underline{29}$ The most comprehensive study examining the rates of autism diagnoses among children receiving the MMR vaccine found a prevalence of 0.138 percent, or roughly 1 in 724 children. .30 Notably, this risk rate was slightly lower than the one found in the control group of unvaccinated children, further refuting false claims about a causal link between the MMR vaccine and autism. $\underline{31}$ Still, if one were reluctant to accept this evidence, a simple comparison between the risk of serious consequences from the disease ( 1 in 212) and the risk of the main condition that generates fears about the vaccine (1 in 724) shows that the benefits would still outweigh even perceived costs. Comparisons with all the other recommended pediatric vaccines would similarly reveal much greater benefits from the vaccines than the costs of potential serious side effects because the current vaccines target highly contagious and often severe diseases, dramatically reducing the risk in each case, typically without any threat of serious side effects. $\frac{32}{2}$

While the benefits of vaccines thus outweigh the risks, this conclusion does not tell the whole story. In fact, this assessment reflects only an aggregate calculation, especially for vaccines' benefits, because a central advantage of vaccines lies in their ability to protect an entire population rather than an individual. Granted, vaccines work on an individual basis, and they are designed to provide the recipient with immunity from a potentially harmful disease so that if there ever is an outbreak, the vaccinated individual will not fall ill. Yet this individual protection represents a vaccine's second line of defense. The real goal of vaccination is to protect an individual by eliminating the threat of the disease altogether through a process known as herd immunity. The basic idea is that if a high-enough proportion of the population receives a vaccine and thereby becomes immune to a given disease, the virus or bacteria that produces that disease will not be able to spread within that population because the number of potential hosts will be so small. This is effectively what happened in the case of smallpox - so many people received the vaccine that the "wild" form of smallpox has completely died off, and children today are not regularly vaccinated against the disease because it is not a natural threat anymore. Herd immunity is particularly important for those individuals who cannot be vaccinated, either because they are too young to receive the recommended vaccines or because they have medical reasons (such as susceptibility to an allergic reaction) that make vaccination too risky. If the community around them has a high rate of vaccination, 
then these individuals will be protected despite not being vaccinated because a given disease will not reproduce and spread within that community. $\cdot \underline{3}$

The importance of herd immunity adds two curious wrinkles to the cost-benefit analysis of vaccines. First, the effectiveness of herd immunity affects the perception of risk. Recall that the main data for a vaccine's risk assessment are the comparison between the risks of side effects and the risks that accompany the disease(s) in question. This assessment needs to balance both the relative severity of the risks and their relative likelihoods, meaning that parents need to consider not only the gravity of a serious side effect versus the gravity of the symptoms of a given disease, but also the probability of each negative outcome. In certain contexts, this might lead a parent independently to conclude that a less serious side effect was a more dangerous risk than the grave symptoms of a particular disease, as long as they had determined that the likelihood of actually contracting the disease was very low, while the statistical probability of the side effects was significantly higher. While there are scientific data to help in this analysis, most people make this assessment on the basis of perceived risk rather than actual risk, so personal experience with a disease and the public narrative can greatly impact the way parents compare the costs and benefits in practice. $\frac{34}{4}$ To the extent that a vaccine program is effective and produces a high level of herd immunity, the risks of contracting a targeted disease are no longer apparent in a given community. As the dangers of a disease fade from collective memory, the perceived risk of the disease approaches zero, and awareness of its gravity also diminishes because fewer people have direct experience with the presentation of the disease. As a result, people in the community easily underestimate both the risk of contracting the disease and the severity of its symptoms. Meanwhile, as more people receive vaccines, there are more experiences with side effects in absolute numbers, even if the rate of side effects remains unchanged. This prompts people in the community to overestimate the risk of experiencing a side effect and, possibly, to overestimate the gravity of those side effects in relative terms. Ironically, then, effective vaccines can undermine herd immunity by skewing the perceived risks in a community away from the disease and to the side effects, even when the actual risks and the true severity of each remain the same. $\underline{35}$

Second, although herd immunity cannot change the severity of a disease, it will eventually affect real risk rates and not just perceived ones. After all, the premise of herd immunity is that a threshold percentage of vaccinated individuals within a community can entirely prevent a given disease from circulating. The threshold level protects everyone in a specific population, both the vaccinated and the unvaccinated. At the same time, however, herd immunity does not discriminate between the reasons individuals are unvaccinated; as long as the overall vaccination rate of the population around an individual is high enough, he or she will be protected from the disease. This fact turns a strictly cost-benefit analysis of vaccines into a sort of "prisoner's dilemma," wherein the optimal outcome for a self-interested individual can be achieved only if everyone else eschews their own self-interest. $\frac{36}{}$ More specifically, if a parent expects that virtually everyone else in the community will be vaccinated, then he or she can reasonably hope that his or her children will be protected from a vaccinepreventable disease by virtue of herd immunity, with or without their own vaccines. Thus, families living in a highly vaccinated community could avoid both the risks of the disease and the risks of vaccine side effects by relying on herd immunity. In fact, from an individual parent's perspective in isolation, this is an ideal outcome

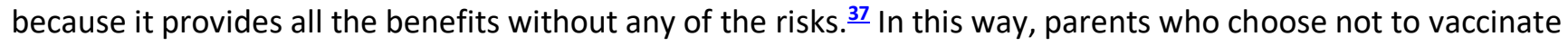
their children make a perfectly justifiable choice, provided they live in a community with sufficiently strong herd immunity. The problem-and the prisoner's dilemma-is that this choice is rational only on an individual level. If everyone were to make this same choice, no one would benefit, and in truth, all would suffer.

In terms of the basic risk calculus that parents are supposed to perform as a matter of due diligence and informed consent, pediatric vaccines thus pose a peculiar problem in today's environment, where the reigning emphasis on autonomy in bioethics champions self-interest as the key to rational thinking. According to this view of rationality, the best choice for a rational actor to make can yield an optimal outcome only if no one else 
in the community acts on a similarly self-interested basis. If, however, everyone proceeded as a self-interested rational actor, then everyone would end up with greater risks. Consequently, the best-case scenario for the individual is at odds with the best-case scenario for the community as a whole. One can easily see why so many parents are troubled by this choice. Fortunately, Catholic social teaching is especially adept at navigating tensions between individual goods and the common good because it begins with an affirmation of the rights of the individual while simultaneously insisting that the human person can flourish only within a well-maintained

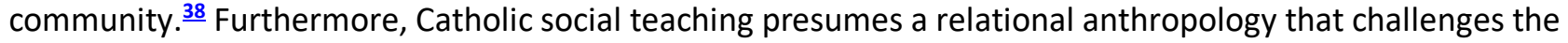
reduction of rationality to self-interest alone, encouraging a view of pediatric vaccines that rejects the prisoner's dilemma of an autonomy-based bioethics as a misinterpretation of moral responsibility. In this way, Catholic social teaching offers the resources to calm the fears of anxious parents while also promoting public health and thus the common good.

\section{Ethical Discernment through the "Permanent Principles" of Catholic Social} Teaching

For all the talk of Catholic social teaching as if it were a monolithic tradition, the truth is that a remarkable diversity characterizes the church's approach to social concerns. Even when one focuses exclusively on the encyclical trajectory, shifts in emphases and changes in social context have introduced a significant degree of heterogeneity. ${ }^{.9}$ This reality is reflected in the varied attempts to generate a list of principles or themes that would synthesize the most important emphases of Catholic social teaching. There are, it seems, as many lists as there are list makers. ${ }^{40}$ Still, there is a certain degree of unity amid this diversity, for many of the lists refer to the same basic ideas even though they employ different language. Provided the longer lists are used in the interpretation, then, a reasonable account can be built around the four "permanent principles of the Church's social doctrine" identified by the Pontifical Council for Justice and Peace (PCJP): the dignity of the human person, the common good, subsidiarity, and solidarity. $\underline{\underline{41}}$

While this collection of principles might seem reductionistic in some ways, the creation of one set of principles is an especially useful step in the application of Catholic social teaching to an applied issue like pediatric vaccines. Ordinary Catholics are much more likely to assess their personal choices in light of the church's social ethics if they can work with a concise, and readily applicable, distillation of the social tradition. A shorter list is therefore justified as a matter of practical considerations, and then this specific list is further warranted for two reasons. First, this list comes directly from a dicastery of the Roman Curia and therefore reflects the most authoritative statement of the Catholic hierarchy for synthesizing the various emphases of Catholic social teaching. Second, each of these four principles can incorporate other subsidiary themes found in the documents of the church's social tradition and in the work of contemporary scholars. Thus, when applied to the issue of pediatric vaccines, these four principles lead moral agents to consider the specifics of Catholic social teaching beyond the surface level of catchphrases, facilitating a deeper form of ethical analysis that similarly moves beyond a tired reliance on autonomy to confront a bioethical issue in a robustly theological fashion.

\section{The Dignity of the Human Person}

The principle of the dignity of the human person is variously called "the bedrock principle of Catholic social teaching" and "the foundation of all the other principles," so it is a fitting point of departure for concrete ethical discernment inspired by the church's social tradition. $\frac{42}{A}$ At its most basic level, the principle of human dignity affirms the inherent worth of every human person. This may seem tautological, but it is not, for one could defend a different account of human dignity that expected each human person to earn or prove her or his worth. $\underline{43}$ Catholic social teaching, however, emphasizes the inherent nature of human dignity, building on the 
claim that every human person is made in the image and likeness of God and destined for union with God to assert that dignity is God-given and not human-made. ${ }^{44}$ The principle of human dignity therefore encompasses some of the other ideas that appear as distinct themes or principles in longer lists of Catholic social teaching principles. For example, the sense that all humans are equally bearers of the image of God lends immediate support to the idea of human equality, for there is no legitimate basis for discrimination when everyone shares the same foundational character. $\underline{45}$ In addition, respect for human life is an essential component of the principle of human dignity, $\underline{46}$ because every human person has an irreducible value that cannot be destroyed..$^{47}$ Finally, the principle of human dignity also serves as a valuable foundation for the promotion and protection of human rights, as the Catholic social tradition has long insisted that "no [one] may with impunity outrage that human dignity which God himself treats with great reverence," a position that has turned into an explicit defense of the rights to freedom of conscience and religion, to work and association, to movement and political participation, and to a decent standard of living. $\frac{48}{\text { The }}$ These corollary convictions help to flesh out the significance of the principle of human dignity in Catholic social teaching, and they can each, in turn, help illuminate pertinent issues at stake as parents discern how they will handle pediatric vaccinations.

To begin, the principle of human dignity's stress on the inherent and irreducible worth of every human person gives credence to the idea that parents should evaluate safety concerns as they make a decision about pediatric vaccines. As John Paul II explained (echoing Immanuel Kant), affirming the principle of human dignity by "recogniz[ing] in [one]self and in others the value and grandeur of the human person" necessitates an acknowledgment of each human being as an end in herself or himself and not as a means to some other end. ${ }^{49}$ Thus, a conscientious evaluation that weighs the personal effects of vaccines - both good and bad-is entirely consistent with a respect for each child as an end and not a means. After all, the principle of human dignity is intimately tied to the protection of life and the promotion of other human rights, including the right to a healthy quality of life. $\stackrel{50}{ }$ Given the dangerous nature of the diseases from which vaccines offer protection, a quick dismissal of all vaccines because of the possibility of side effects does not show an adequate recognition of the innate dignity of each child because such a decision undermines that child's rights to life and appropriate health care. The principle of human dignity therefore validates the general strategy of factoring risks and rewards into the ethical discernment of vaccines. At the same time, the corollary aspects of this first, foundational principle of Catholic social teaching offer two further insights for refining this evaluation so that it will be conducted in a morally responsible fashion that avoids the pitfalls of a strictly utilitarian analysis.

First, the principle of human dignity demonstrates that the consideration of risks and rewards cannot be confined to one's own children alone. Precisely because the principle of human dignity is rooted in the creation of every human person in the image and likeness of God (coupled with the intimate association of divinity and humanity in the Incarnation), respect for human dignity demands acceptance of the intrinsic equality of all human persons. In practice, this entails resisting the urge to prioritize absolutely one's own family ahead of all others. Admittedly, parents do have a right, and indeed an obligation on the basis of the order of love, to show special concern for their children and their children's rights, $\underline{\underline{51}}$ but they do not have the authority to use this concern as a shield against the same rights of others. In this sense, the principle of human dignity's insistence on equality aligns with some of the more challenging statements of the gospels, wherein Jesus questions family ties in order to challenge the idolization of blood kinship at the expense of others in need (e.g., Matt 10:37-38,

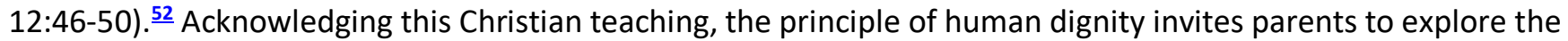
effects of their vaccine decisions on both their own children and others' children. Given the nature of herd immunity, this suggests a predisposition to vaccination, but in light of the need to treat children as ends and not means, it is not an absolute predisposition; individual risk factors must still be taken into account.

Second, because the principle of human dignity is directly tied to the protection of human life, this element of Catholic social thought also indicates that parents need to be concerned about the research process that 
generates pediatric vaccines. Specifically, parents should be alarmed about the use of organs, body parts, and organic material from victims of abortion because this means of procurement is an affront to the human dignity of the unborn child. $\underline{53}$ As alluded to above, this is a significant ethical concern in the case of pediatric vaccines because many of the vaccines currently on the market were developed in cell lines derived from aborted human fetuses. In fact, in the United States, four of the recommended pediatric vaccines (against rubella, hepatitis A, chicken pox, and polio) are implicated, and there are no alternatives for three of those four. $\frac{54}{4}$ The Vatican, through the Pontifical Academy for Life, has explored the ethical implications of this situation using the traditional principle of cooperation with evil to insist that the current link to the immoral abortion procedures is remote enough, and the risks to public health from refusing to use any of these vaccines are great enough to justify using pediatric vaccines that were developed in cell lines from aborted fetuses when no other alternatives are available. Significantly, though, the Pontifical Academy for Life also stressed that this decision still entangled today's parents with the evil of abortion, so the academy insisted that when parents opt for these unethically produced vaccines out of necessity, they should also pressure vaccine producers to create new vaccines for the same diseases using ethical means. $\frac{55}{}$

As the application of the principle of human dignity to the issue of vaccine development makes clear, this bedrock principle of Catholic social teaching entails a balancing act. The principle of human dignity thus sets the stage for a fuller assessment of the ethical issues involved in pediatric vaccines because it justifies an analytical approach that highlights the pertinent questions, but it does not, on its own, provide clear answers to the queries it raises. Fortunately, the other three permanent principles of Catholic social teaching each add specificity to this balancing act and provide the tools to answer the questions identified by the principle of human dignity.

\section{The Common Good}

After the principle of human dignity, the next principle identified by the PCJP is the principle of the common good. The church's social tradition identifies the common good as "the sum total of the conditions of social life enabling groups and individuals to realize their perfection more fully and readily." $\underline{\text { }}$ In this sense, the common good is about the larger social, political, and even material environment in which people live, encouraging the perfecting of each of these so that everyone has an equal opportunity to flourish. The principle of the common good therefore complements the principle of human dignity and extends the latter's emphasis on equality, ensuring that the promotion of human rights for all is not used as an excuse to curtail the opportunities of some. ${ }^{57}$ At times, the principle of the common good has been parsed out to include a corollary principle of participation, on the basis of the claim that everyone has a right and an obligation to participate in the shared economic, political, and social life of the community, so that they might both share in the benefits of the common good and contribute to the specification and realization of their community's collective good. $\underline{\underline{58}}$ Indeed, this participation is constitutive of each person's dignity and flourishing as well. In addition, the common good also has a natural affinity with care for the environment, which, for example, could be incorporated into the

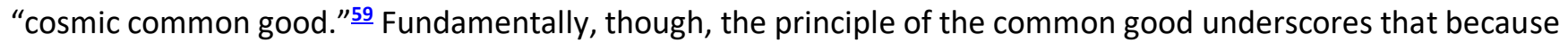
the human person is innately social, there is a shared good that is necessary for full human flourishing and which cannot be achieved in isolation; in fact, it is greater than the goods any individual can create when acting alone. $\frac{60}{H}$ Hence, the principle of the common good is particularly well suited to the question of pediatric vaccines because the communal benefit of herd immunity is precisely this kind of good.

Given the specifics of the common good in the Catholic tradition, this principle reveals a new way of evaluating the risks and rewards of vaccines that both presumes and honors the social nature of the human person, fundamentally reframing the apparent dilemma that results from relying on a strictly self-interested version of 
rationality in moral reasoning. As mentioned above, the best-case scenario for any individual in a strictly selfinterested cost-benefit analysis is to refuse a vaccine (thereby avoiding any potential side effects) that everyone else in the community agrees to receive (thereby providing herd immunity for the vaccinated community and the unvaccinated individual). This would be a logical choice for an individual, but it has an inevitable problem at a social level because if everyone were to universalize this "maxim," as Kant would say, then the system would fall apart. $\underline{61}$ The principle of the common good targets this contradiction because it denies the legitimacy of championing self-interest in a way that undermines the community's realization of a collective good. Further, because the common good stresses both the right and the obligation to participate in the creation, realization, and distribution of collective goods, the principle of the common good also identifies a responsibility incumbent on "all citizens, however indirect their stake, to make significant sacrifices for such improvements that will bring broad benefits to society, including future generations." $\underline{\mathbf{6 2}}$ In the case of vaccines, this would imply a willingness to accept the individual risks associated with vaccines for the sake of the greater collective good of herd immunity. Obviously, there could be instances where this is not possible for a variety of medical reasons, but those kinds of circumstances properly transform the moral evaluation, creating legitimate exceptions that honor one's responsibilities for self-care and rightly ordered family concern. Overall, the principle of the common good militates against a facile reliance on personal utility in the evaluation of pediatric vaccines because this principle demonstrates that all persons in the community are interdependent, and therefore each has a responsibility to do what she or he can to promote the benefit of the community as a whole. For most people in most situations, accepting the low risks of pediatric vaccines as recommended is precisely the kind of thing they can do to promote the common good.

The common good promotes the moral legitimacy of pediatric vaccines not just at the level of the general principle, but also when one considers the common good's corollary commitment to the care of creation. Typically, discussions linking vaccines with environmental concerns focus on the possibly negative effects of certain preservative ingredients on the ecosystem, but there is not a significant amount of proven risk at this level. $\underline{63}$ There is, however, another environmental risk with established dangers: antibiotic resistance. Antibiotic resistance is an environmental problem because entire ecosystems are threatened by the prevalence of antibiotic-resistant bacteria, which can reproduce with impunity, dramatically upending the balance in the

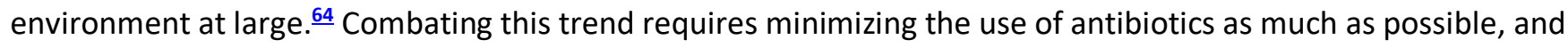
this is where pediatric vaccines can contribute to the care of creation because some of the diseases targeted by these vaccines are caused by bacteria (e.g., pertussis, diphtheria, tetanus, Hib, and pneumonia). When vaccines prevent diseases with bacterial causes, the vaccines provide a form of immunity that does not require antibiotics. If someone who had not been vaccinated were to catch one of these diseases at a later date, they would likely (or necessarily, depending on the disease) need antibiotic treatments. The vaccine therefore abrogates the need for these drugs, decreasing the prevalence of antibiotics in the ecosystem. Insofar as the principle of the common good commends the care of creation, then, it also reveals that parents should be inclined to have their children vaccinated as a way of embodying not only social but also environmental concerns.

The principle of the common good therefore offers parents compelling reasons to shift away from the narrow cost-benefit analysis of pediatric vaccines toward a socially conscious perspective that better embodies the Catholic understanding of the human person as a fundamentally relational being. This new approach breaks down the stalemate of an exclusively individualistic assessment and suggests a readiness to accept the comparatively low risks associated with pediatric vaccines for the sake of substantial communal benefits. This conclusion reflects a communitarian impulse akin to the one that marks much of the secular public health discourse, but it also adds a distinctively Catholic flavor to this interpretation by insisting that concern for the common good must not be reduced to utilitarian prioritization of the good of the group over the good of the individual. Such a utilitarian analysis would not admit any space for variation, but a Catholic commitment to the 
common good emerges from and complements the church's emphasis on human dignity, so it admits the possibility of exception to the general rule when individual circumstances make vaccinations overly dangerous. One cannot put a human person at excessive risk merely because the benefits could or would be good for the community, for to do so would be to deny the irreducible value of each human person that the principle of human dignity affirms. Precisely to avoid this kind of utilitarian reductionism, the PCJP insists that all of the permanent principles of the church's social doctrine must be kept together, and this means interpreting the common good not only in light of human dignity, but also in terms of the next principle of subsidiarity. $\underline{\underline{65}}$

\section{Subsidiarity}

The principle of the common good may promote a certain degree of deference to one's communal responsibility, but the principle of subsidiarity quickly reveals that this is not the full extent of one's relational obligations. First introduced by Pope Pius XI in Quadragesimo Anno as "the principle of 'subsidiary function,'” the principle of subsidiarity specifically referred to the decentralization of government power, encouraging "the supreme authority of the State ... to let subordinate groups handle matters and concerns of lesser importance" so that the state might focus on the large-scale challenges that local communities and organizations could not handle on their own. ${ }^{66}$ Subsequent popes have developed the idea to emphasize its alliance with the principle of human dignity, suggesting that a willingness to leave social and political power at the lowest possible level "respects personal dignity by recognizing in the person a subject who is always capable of giving something to

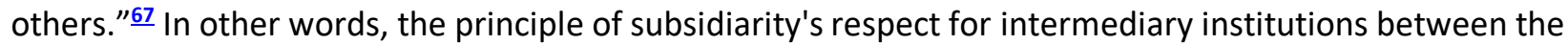
individual and the state affords each person the chance to participate more fully in the self-governance of his or her community, thereby affirming each individual's dignity through the exercise of freedom and also allowing each person to contribute to the common good more fully. The principle of subsidiarity thus evinces a profound respect for the human person, encouraging and empowering participation in the common good, but it also underscores the importance of the family, a social unit that plays a central role in the question of pediatric vaccines. In fact, the role of the family is so important in Catholic social teaching that some theologians prefer to identify it as its own principle, ${ }^{68}$ yet it also fits nicely within the principle of subsidiarity because the church's social tradition identifies the family as the first and most essential intermediary group that allows inherently social human beings to flourish. $\frac{69}{}$ The principle of subsidiarity therefore points to the family as an innate social good, suggesting that parents have the right to make decisions that will promote the well-being of their family.

In relation to pediatric vaccines, the principle of subsidiarity would seem to support the commitment to patient autonomy that defines contemporary medical ethics. To a degree, this is true, although only insofar as autonomy is properly understood. Just as the principle of human dignity encourages parents to consider the risks and rewards of vaccines so that they do not treat their children merely as means to a communal end, so the principle of subsidiarity indicates that parents have the right to make decisions about their children's care in a way that is free from undue coercion. The Catholic understanding of true human freedom, however, is not reducible to the typical notion of autonomy as an exercise of total independence. Instead, Catholic social teaching indicates that "genuine freedom" lies not in the ability to choose any outcome (i.e., perfect autonomy), but the ability to achieve the (morally) good outcome. $\stackrel{70}{ }$ As Pope John Paul II explained, human freedom is not about freedom from moral obligations, but the freedom to fulfill those obligations. $\underline{71}$ Consistent with this interpretation, Catholic social teaching avows that every right comes with accompanying responsibilities, and in this way, a Catholic approach to bioethics that is attentive to the church's social doctrine represents a stark contrast to the typical assumptions of bioethics today. $\underline{72}$ Thus, while the principle of subsidiarity acknowledges that families have the right to make decisions about their children's health, it also indicates that those decisions must be made with an eye toward one's social responsibilities, for "an active commitment to our neighbour ... is not limited to one's own family, nation or State, but extends progressively to all mankind." $\underline{73}$ Consequently, the 
principle of subsidiarity creates a certain kind of tension, as obligations to care for one's family are affirmed while responsibilities to the larger community are simultaneously reinforced.

The chief implication of this tension is a moral imperative to evaluate all of the stakes in decisions about pediatric vaccines. A quick choice to reject vaccination in order to avoid the accompanying risks is unacceptable, because this would represent the exercise of a right without any consideration of its accompanying responsibilities. A conscientious analysis in conversation with a child's primary care provider that identifies a specific risk for an individual child from a particular vaccine would, however, show a readiness to use one's rights only in a manner that respects their accompanying responsibilities too. The key distinction between these two examples is the agent's disposition toward the common good, which the principle of subsidiarity both presumes and affirms. The first approach employs an individual's rights as a shield from the community's concerns, projecting an inadequate vision of human freedom that denies social connectivity. Parents in the second example, meanwhile, begin with an interest in doing what they can to help the community, prescinding from that responsibility only when evidence reveals that the choice that would best benefit the community is not something that the parents can do in light of present circumstances. The first example undermines the principle of subsidiarity, while the second preserves its tensions. Rather unsurprisingly, these implications put the principle of subsidiarity in line with the principle of human dignity and the principle of the common good, confirming the rights of individuals and families to assess their direct risks, while also positioning those rights in relation to the shared public good of communal health. The final permanent principle of Catholic social teaching, solidarity, serves only to strengthen the connections between these three, adding a further rationale for a careful, socially conscious analysis of pediatric vaccines.

\section{Solidarity}

Solidarity is variously described as a principle of Catholic social teaching and a moral virtue, but it is generally understood to highlight two distinct responsibilities. $\stackrel{74}{ }$ First, solidarity stresses the inherent interdependence of all human beings and therefore invites each individual to consider the implications of her or his decisions for other people. In this sense, John Paul II spoke of solidarity as "a firm and persevering determination to commit oneself to the common good; that is to say to the good of all and of each individual, because we are all really responsible for all." 75 Of course, the realization of the common good requires large-scale cooperation, which necessitates social structures. Second, therefore, the principle of solidarity also indicates that the basic structures of society should be governed by justice in particular so that these structures can be better oriented to the full flourishing of each human person. $\underline{76}$ Given both of these emphases, it is fitting that the principle of solidarity is also closely aligned with the preferential option for the poor, because the recognition of human interconnectedness needs to begin with those who are most marginalized, and the promotion of the common

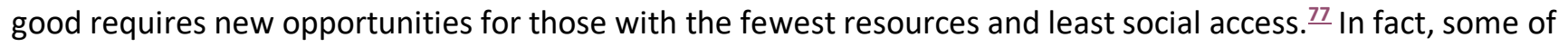
the most prominent uses of solidarity in the Catholic tradition have come from the work of liberation theologians, who employed the idea to stress the need for the church in Latin America to stand alongside the poor in order to challenge the structures keeping them in poverty. ${ }^{78}$ As a result of this background, liberation theology speaks of the deep concern for and accompaniment of the poor as the "primary solidarity." $\underline{\text { "99 }}$ At a practical level, then, the principle of solidarity asks Catholics to consider the implications of their actions on others in the community and to pursue social policies that will ensure access to the building blocks of human flourishing. In both instances, the poor constitute a privileged point of reference for these reflections.

With respect to pediatric vaccines, the principle of solidarity reemphasizes the need to incorporate the common good into one's ethical discernment, but it then adds a new element by insisting that the common good should be informed by a special concern for those who are most at risk. Here, the principle of solidarity seriously calls into question the current practice of refusing vaccines for nonmedical reasons in the United States because such a decision typically places a substantial burden on the poor and vulnerable. Obviously, the people most at risk 
from vaccine refusals are those who remain unvaccinated. ${ }^{80}$ In the case of vaccines, the most vulnerable therefore includes children whose parents have decided not to vaccinate them in order to remove the risks of vaccine side effects, but it also encompasses children who cannot get vaccines, either because they are too young (only one recommended vaccine can be given before a child is six weeks old), because they have a medical contraindication, or because their families lack the resources and access to obtain the vaccines. Parents who choose not to vaccinate their children take this risk on themselves as agents of their children's health care, but those children who cannot get vaccinated bear the same burden without the benefit of anyone exercising free will on their behalf. Although the risk is the same for both groups, there is something qualitatively distinct about the vulnerability of the latter group because these children and their families are left at the mercy of forces completely beyond their control in a way that families in the former group are not. Furthermore, children who are not vaccinated for reasons of parental choice are usually from higher-income families, while children

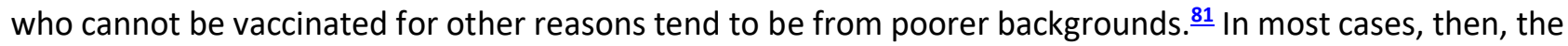
parents who choose not to vaccinate their children are accepting a risk that they normally have the means to address at a later date (if that should become necessary), but they also create a risk that disproportionately burdens the children whose families have fewer resources to handle medical complications.

From the perspective of the principle of solidarity, this outcome is untenable because it allows certain individuals to exert their social privilege at the expense of the poor, who are supposed to be the beneficiaries of a preferential option. Given the current distinctions between accepting risks, "the prerogative of the affluent, and being at risk, the fate of the poor," is unethical to opt out of pediatric vaccines for nonmedical reasons as long as there are structural impediments to universal access to preventative medicine. Without that protection, the acceptance of risk by some will always represent a burden on others who do not have the same luxury of choice.

Importantly, this analysis from the principle of solidarity also extends to the structural level. Precisely because the poor and medically vulnerable bear the greatest costs when parents refuse pediatric vaccines, a solidaristic concern for the poor indicates that Catholics ought also to support social policies that will lessen the burden on these vulnerable groups. Chief among these are compulsory vaccination laws. While this might seem to require a radical leap in moral thinking, since it represents a public policy concern in the midst of a conversation about parents' moral responsibilities toward their own children, a central conviction of Catholic social teaching is that personal concerns and social concerns are not so easily divisible. Furthermore, since the Compendium of the Social Doctrine of the Church declares that "solidarity must be seen above all in its value as a moral virtue that determines the order of institutions," the principle of solidarity can never remain at the level of personal moral reflection alone; it must always include a commitment to structural reform for the sake of the common good. $\frac{83}{}$ The link between Catholic moral reasoning and specific legal proposals may be complicated, but the principles of Catholic social teaching certainly have a role to play in this process, and in this case the principle of solidarity generates strong arguments in favor of compulsory vaccination laws.

Currently, all US states and the District of Columbia have laws requiring children to be up-to-date on the recommended vaccine schedule before they can be enrolled in day care or public (and oftentimes private) school. ${ }^{84}$ Every state also has specific policies granting exceptions to this requirement under certain circumstances. The most stringent policies permit exemptions from vaccine mandates only in cases where medical contraindications or religious objections have been duly established with the state. In other cases, exemptions are permitted on the basis of personal philosophical commitments, which could range from an objection to Western medicine to a rejection of the authority of the state to impose a public health mandate. In many of these states, philosophical exemptions are easily obtainable, quickly diluting the force of a compulsory vaccination law. $\underline{.5}$ For some, these exemptions may seem like reasonable concessions to the legitimate rights of

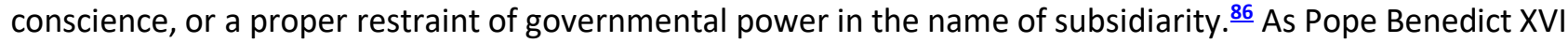


insisted, though, "The principle of subsidiarity must remain closely linked to the principle of solidarity and vice versa"; so restraints on government power in the name of subsidiarity must also serve the common

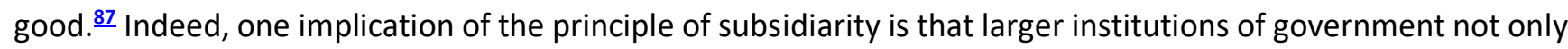
can but also should exercise authority when lower-level institutions cannot ensure the common good on their own. $\underline{8}$

In the case of pediatric vaccines, compulsory vaccination laws are consistent with the church's social doctrine for two reasons. First, the public health risks of refusing vaccines is especially grave-a fact the church acknowledged in justifying the licit use of vaccines derived from aborted fetuses when no other alternatives are available. ${ }^{89}$ Second, the absence of laws mandating vaccines would lead to lower rates of vaccination and higher rates of disease, as studies already reveal that higher exemption rates translate to greater risks for the population at large. .90 Since easier exemption policies lead, unsurprisingly, to greater exemptions and thus lower vaccine rates, Catholics should, as a matter of solidarity's concern for structural justice, support compulsory vaccination laws that restrict exemptions to cases of medical necessity and religious observance, with the latter narrowly defined to create space for individuals-like Christian Scientists-whose religious convictions consistently oppose all medical interventions, but not for parents who simply object to a particular vaccine for personal reasons. $\underline{11}$ Of course, prudential judgment will need to be exercised in the evaluation of particular pieces of legislation, but a general commitment to this overarching policy is appropriate. ${ }^{92}$ By coupling this support with an attention to the social ramification of their vaccine choices, parents will faithfully embody the twofold commitment of the principle of solidarity.

\section{Conclusion: Practical Implications}

The four permanent principles of Catholic social teaching, while not specifically designed as bioethics principles, nonetheless help to highlight the ethical issues involved in pediatric vaccines. Each of these principles adds new dimensions to the moral analysis of this case, and together they all point to some practical implications for parents trying to navigate the pressures surrounding vaccines today. Specifically, the four principles of Catholic social teaching combine to indicate that parents should adopt a stance of deference to the common good and thus prioritize the established public health benefits of pediatric vaccines over their speculative risks. In concrete terms, this shifts the burden of proof. In contrast to the "precautionary principle," which would require clear demonstration of zero risk before accepting a vaccine, this stance acknowledges the difficulties of definitively proving the absence of all risk and instead puts the onus on proving the existence of specific threats. $\underline{\underline{93}}$

To offer a legal analogy, this stance encourages parents to approach pediatric vaccines with a presumption of innocence. Importantly, this does not eliminate the possibility of guilt. Just as defendants presumed innocent can be proven guilty on the basis of the evidence, so specific vaccines might be "proven guilty" for the same reasons. This could occur on one of two levels: either a specific vaccine could be shown to have significant risks for everyone who was vaccinated-as the original rotavirus vaccine did-or a specific vaccine could be shown to pose a significant threat to particular populations-as some vaccines are shown to create a dangerous risk of anaphylaxis in children with egg allergies. If either of these circumstances is established by a reasonable standard of evidence (and, given the challenges of proving causality and the fact that children's well-being is at stake, a "preponderance of evidence" standard, rather than the strictest "beyond a reasonable doubt" standard, seems justifiable for pediatric vaccines), then the vaccines will be considered "guilty," and parents will have moral cause to refuse a given vaccine, either outright in the former case or narrowly in the latter if their child is in a high-risk population. Of course, consistent with their commitment to human dignity, the common good, subsidiarity, and solidarity, parents in these cases should also look for less risky ways to contribute to the community's herd immunity than giving up on a vaccine entirely, which could mean requesting another manufacturer's version of the vaccine if available or advocating for the creation of new vaccines that would 
protect against the same disease with fewer risks. By taking this approach, parents will demonstrate a real concern for their own children's health and well-being without dismissing the health claims of the rest of the community.

In this manner, Catholic social teaching prompts an approach to pediatric vaccines that moves beyond a simple analysis of costs and benefits for a single child to a more holistic evaluation of the morality of vaccines in a social context. This approach yields practical insights for parents, revealing that Catholic social teaching can have an appreciable effect on the everyday moral thinking of ordinary Catholics. Just as importantly, this application of the four permanent principles of Catholic social teaching illustrates that there is a realistic alternative to the reliance on individualistic interpretations of autonomy and informed consent that characterizes the typical approach to bioethics today. In its place, Catholic social teaching offers a way to see bioethical issues from the perspective of a theological anthropology that regards the human person as irreducibly social, yielding a framework for ethical discernment that is much more faithful to the totality of one's moral responsibilities. Ultimately, this framework can, and should, extend beyond bioethics to all matters of ethical discernment, so that concerns about human dignity, the common good, subsidiarity, and solidarity will not be restricted to the theoretical sphere of academic theology, or narrowly applied to a handful of bioethics questions, but will instead have an impact throughout the concrete reality of ordinary life. This will certainly be difficult to achieve completely, but there is no reason this important journey cannot begin with a little more critical reflection on pediatric vaccines and Catholic social teaching.

${ }^{1}$ Johnson, Kelly S., "Catholic Social Teaching," in Gathered for the Journey: Moral Theology in Catholic Perspective, ed. McCarthy, David Matzko and Lysaught, M. Therese (Grand Rapids, MI: William B. Eerdmans, 2007), 225-, at 232.

${ }^{2}$ The author would like gratefully to acknowledge the assistance of his wife, Kate Kelly, CPNP, whose insights and experience as a pediatric nurse practitioner led to many conversations informing this article and strengthening its argument.

${ }^{3}$ Cahill, Lisa, Theological Bioethics: Participation, Justice, Change (Washington, DC: Georgetown University Press, 2005), 18.

${ }^{4}$ To give just one example, fears of polio were so strong when Jonas Salk was developing his famous vaccine that local health officials had no trouble securing volunteers for the tests of the as-yet unproven vaccine, and once it was announced that the tests were successful, "people wept openly with relief." Oshinsky, David M., Polio: An American Story (Oxford: Oxford University Press, 2005), 190, 203.

${ }^{5}$ Plotkin, Susan L. and Plotkin, Stanley A., "A Short History of Vaccination," in Vaccines, ed. Plotkin, Stanley A., Orenstein, Walter A., and Offit, Paul A., 6th ed. (St. Louis: Elsevier Saunders, 2013), 1-13. In terms of early objections, the famed Boston minister Cotton Mather encountered stiff resistance when he encouraged an early inoculation practice called variolation to combat a smallpox epidemic in the 1720 s, "to the point at which a grenade was thrown into his house in objection!" Likewise, Louis Pasteur's use of a rabies vaccine to protect two children who had been bitten by rabid dogs "left people aghast" because he used the actual (although weakened) rabies virus and not a substitute pathogen. Ibid., 2, 5.

${ }^{6}$ Macklin, Ruth and Greenwood, Brian, "Ethics and Vaccines," in The Vaccine Book, ed. Bloom, Barry R. and Lambert, Paul-Henri (San Diego: Academic Press, 2003), 119-27, at 120-21; Grady, Christine, "Ethics of Vaccine Research," in Research Ethics, ed. Iltis, Ana Smith (New York: Routledge, 2006), 22-31, esp. 22-23. 
7 On HeLa cells and the polio vaccine, see Skloot, Rebecca, The Immortal Life of Henrietta Lacks (New York: Crown Publishers, 2010), 93-97. The book as a whole chronicles the questionable ethics involved in the initial procurement and creation of HeLa cells. On the issue of vaccines derived from aborted fetuses, see Pontifical Academy for Life, Moral Reflections on Vaccines Prepared from Cells Derived from Aborted Human Foetuses (2005), http://www.academiavita.org/ pdf/documents/pav/moral relflections on vaccines e n.pdf.

${ }^{8}$ Eiser, Arnold R., The Ethos of Medicine in Postmodern America: Philosophical, Cultural, and Social Considerations (Lanham, MD: Lexington, 2014), 143-44, 147. See also Lysaught, M. Therese, "Respect: Or, How Respect for Persons Became Respect for Autonomy," Journal of Medicine and Philosophy 29, no. 6 (2004): 665-80.

${ }^{9}$ National Center for Immunization and Respiratory Diseases, "Recommended Immunization Schedule for Children and Adolescents Aged 18 Years or Younger, United States, 2017," Centers for Disease Control and Prevention, last modified February 6, 2017, https://www.cdc.gov/vaccines/schedules/hcp/imz/child-adolescent.html.

${ }^{10}$ See Orenstein, Walter A. and Hinman, Alan R., "The Immunization System in the United States-The Role of School Immunization Laws," Vaccines 17, supplement 3 (Oct. 29, 1999): S19-S24, esp. S22-S23.

${ }^{11}$ The number of diseases targeted by pediatric vaccines increased more than twofold from 1983 to 2005. Largent, Mark A., Vaccine: The Debate in Modern America (Baltimore: Johns Hopkins University Press, 2012), 15.

${ }^{12}$ Omer, Saad B., Pan, William K. Y., Halsey, Neal A., Stokley, Shannon, Moulton, Laurence H., Navar, Ann Marie, Pierce, Mathew, and Salmon, Daniel A., "Nonmedical Exemptions to School Immunization Requirements: Secular Trends and Association of State Policies with Pertussis Incidence," Journal of the American Medical Association 296, no. 14 (Oct. 11, 2006): 1757-63; Liz Szabo, "Refusing Kids' Vaccine More Common among Parents," USA Today, last modified May 3, 2010, http://usatoday30.usatoday.com/news/health/2010-05-04-vaccines04 ST N.htm.

${ }^{13}$ Maggie Fox, "Vaccine Rates Are Up, But So Are Refusals," NBC News, last modified January 19, 2018, https://www.nbcnews.com/health/health-news/vaccine-rates-are-so-are-refusals-n838811.

${ }^{14}$ Offit, Paul A., Deadly Choices: How the Anti-Vaccine Movement Threatens Us All (New York: Basic Books, 2011), 2-11.

${ }^{15}$ Ibid., 27-44.

${ }^{16} \underline{\text { Ibid. }}$, 91-92.

${ }^{17}$ Ibid., 93-96; Largent, Vaccine, 73-74. Eggertson, Laura, "Lancet Retracts 12-Year-Old Article Linking Autism to MMR Vaccines," Canadian Medical Association Journal 182, no. 4 (March 2010): E199-E200; Editors of The Lancet, "Retraction-Ileal-Lymphoid-Nodular Hyperplasia, Non-specific Colitis, and Pervasive Developmental Disorder in Children," The Lancet 375, no. 9713 (February 2, 2010): 445.

${ }^{18}$ Largent, Vaccines, 75-76, 83-87, 88-93. Largent notes that roughly 20 percent of US parents believe that vaccines can cause autism (68).

19 Offit, Paul and Bell, Louis M., Vaccines: What You Should Know, 3rd ed. (Hoboken, NJ: John Wiley, 2003), 1825. 
${ }^{20}$ National Center for Immunization and Respiratory Diseases, "Possible Side-Effects from Vaccines," Centers for Disease Control and Prevention, last modified May 8, 2017, https://www.cdc.gov/vaccines/vac-gen/sideeffects.htm.

${ }^{21}$ Offit, Paul A. and Moser, Charlotte A., Vaccines and Your Child: Separating Fact from Fiction (New York: Columbia University Press, 2011), 175.

${ }^{22}$ Centers for Disease Control and Prevention, "Suspension of Rotavirus Vaccine after Reports of Intussusception-United States, 1999," Morbidity and Mortality Weekly Report 53, no. 34 (September 3, 2004): 786-89; Zanardi, L. R., Haber, P., Mootrey, G. T., Niu, M. T., and Wharton, M., "Intussusception among Recipients of Rotavirus Vaccine: Reports to the Vaccine Adverse Event Reporting System," Pediatrics 107, no. 6 (June 2001): E97.

${ }^{23}$ National Center for Immunization and Respiratory Diseases, "Possible Side-Effects."

${ }^{24}$ Offit and Bell, What You Should Know, 88, 90.

25 Ibid., 22.

${ }^{26}$ Oshinsky, Polio, 161.

${ }^{27}$ Offit and Moser, Vaccines and Your Child, 149; Offit and Bell, What You Should Know, 49; National Center for Immunization and Respiratory Diseases, "Possible Side-Effects."

${ }^{28}$ Offit and Moser, Vaccines and Your Child, 18.

${ }^{29}$ Statistics based on author's own calculations: 20,000 birth defects among 4,257,850 live births. Vital Statistics of the United States 1960, vol. 1, Natality (Hyattsville, MD: United States Department of Health, Education, and Welfare, 1964), section 1.

${ }^{30}$ Madsen, Kreesten, Meldgaard, Hviid, Anders, Vestergaard, Mogens, Schendel, Diana, Wohlfahrt, Jan, Thorsen, Poul, Olsen, J $\emptyset \mathrm{rn}$, and Melbye, Mads, "A Population-Based Study of Measels, Mumps, and Rubella Vaccination and Autism," New England Journal of Medicine 347, no. 19 (Nov. 7, 2002): 1477-82, at 1479-80. The percentage and ratio statistics presented here are based on the authors' own calculations: 263 cases of autistic disorder and 345 cases of "other autistic-spectrum disorders" among vaccinated children (total of 608 ) out of 440,655 vaccinated children.

${ }^{31}$ Madsen et al., 1480-82; see also Largent, Vaccine, 122.

${ }^{32}$ For an overview of the effects of the recommended vaccines in relation to the dangers of the diseases they prevent and the possibilities of side effects, see Offit and Bell, What You Should Know, 33-86. For the rotavirus, hepatitis $A$, and flu vaccines that have since been incorporated into the recommendations, see Offit and Moser, Vaccines and Your Child, 134-41, 154-64, and 188-94.

${ }^{33}$ Fine, Paul, Eames, Ken, and Heymann, David L., "'Herd Immunity': A Rough Guide," Clinical and Infectious Diseases 52, no. 7 (April 1, 2011): 911-16. On the eradication of smallpox, see Tucker, Jonathan B., Scourge: The Once and Future Threat of Smallpox (New York: Grove Press, 2001), 39-138.

${ }^{34}$ Offit and Bell describe this practice by referring to the difference between "seen" and "unseen" risks. The risks we can see (e.g., vaccine side effects experienced immediately) often weigh more heavily on us than the risks we cannot see (e.g., the symptoms of a disease contracted in the future), even though the latter are often worse. Offit and Bell, What You Should Know, 21-22. 
${ }^{35}$ This is an important factor in the increase in refusals of pediatric vaccines for nonmedical reasons, as "lower perceived risk of contracting a vaccine-preventable disease, lower perceived importance of vaccinepreventable disease, [and] lower perceived vaccine safety and effectiveness" have all been associated with vaccine refusals and delays. Salmon, Daniel A., Dudley, Matthew Z., Glanz, Jason M., and Omer, Saad B., "Vaccine Hesitancy Causes, Consequences, and a Call to Action," Vaccine 33, supplement 4 (Nov. 2015): D66-D71, at D68.

${ }^{36}$ For more on the notion of a prisoner's dilemma, see Steven Kuhn, "Prisoner's Dilemma," Stanford Encyclopedia of Philosophy, last modified August 29, 2014, https://plato.stanford.edu/entries/prisonerdilemma/.

${ }^{37}$ Macklin and Greenwood, "Ethics and Vaccines," 125-26.

${ }^{38}$ For a succinct account of Catholic social teaching's theological anthropology, see Heyer, Kristin E., "Catholics in the Political Arena: How Should Faith Inform Catholic Voters and Politicians," in Catholics and Politics: The Dynamic Tension between Faith and Power, ed. Heyer, Kristen E., Rozell, Mark J., and Genovese, Michael A. (Washington, DC: Georgetown University Press, 2008), 61-72, at 62-63.

${ }^{39}$ See Coleman, John, "Development of Church Social Teaching," in Official Catholic Social Teaching, ed. Curran, Charles E. and McCormick, Richard A. (New York: Paulist Press, 1986), 169-87.

${ }^{40}$ For instance, the Pontifical Council for Justice and Peace identifies four "permanent principles," the United States Conference of Catholic Bishops specifies seven "themes," Thomas Massaro articulates nine themes, and William Byron describes ten principles. Pontifical Council for Justice and Peace, Compendium of the Social Doctrine of the Church (Vatican City: Libreria Editrice Vaticana, 2004), \$160; United States Conference of Catholic Bishops, "Seven Themes of Catholic Social Teaching," last modified 2005, http://www.usccb.org/beliefs-and-teachings/what-we-believe/catholic-socialteaching/seven-themes-of-catholic-social-teaching.cfm; Massaro, Thomas, Living Justice: Catholic Social Teaching in Action, 2nd classroom ed. (Lanham, MD: Rowman \& Littlefield, 2012), 79117; Byron, William J., "Ten Building Blocks of Catholic Social Teaching," America 179, no. 13 (Oct. 31, 1998): 9-12.

${ }^{41}$ Pontifical Council for Justice and Peace, Compendium, §160 (emphasis in the original); see also §§105-96 more broadly.

42 Byron, "Ten Building Blocks," 10; Pontifical Council for Justice and Peace, Compendium, $§ 160$.

${ }^{43}$ Johnson, "Catholic Social Teaching," 228.

${ }^{44}$ Gaudium et Spes $§ 12,19$, in Tanner, Decrees of the Ecumenical Councils, 2:1075-76, 1079; Massaro, Living Justice, 81.

${ }^{45}$ Massaro, Living Justice, 82; cf. Byron, "Ten Building Blocks," 11.

${ }^{46}$ Respect for life is sometimes treated as a distinct principle, and sometimes identified as an element of the principle of human dignity. Byron, "Ten Building Blocks," 10; cf. USCCB, "Seven Themes"; Massaro, Living Justice, 81-82.

47 Pope John Paul II, The Gospel of Life (Evangelium Vitae), March 25, 1995, §§2, 8, http://w2.vatican.va/content/iohn-paul-ii/en/encyclicals/documents/hf ipii enc 25031995 evangelium-vitae.html. 
${ }^{48}$ Pope Leo XIII, On Capital and Labor (Rerum Novarum), May 15, 1891, §40, http://w2.vatican.va/content/leoxiii/en/encyclicals/documents/hf I-xiii enc 15051891 rerum-novarum.html; see also Pope John XXIII, Peace on Earth (Pacem in Terris), April 11, 1963, §§10-27, http://w2.vatican.va/content/johnxxiii/en/encyclicals/documents/hf i-xxiii enc 11041963 pacem.html; Gaudium et Spes, §27, in Tanner, Decrees of the Ecumenical Councils, 2:1085-86.

${ }^{49}$ Pope John Paul II, After One Hundred Years (Centesimus Annus), May 1, 1991, $\S 41$, http://w2.vatican.va/content/iohn-paul-ii/en/encyclicals/documents/hf ipii enc 01051991 centesimus-annus.html; cf. Kant, Immanuel, Groundwork of the Metaphysics of Morals, trans. and ed. Gregor, Mary and Timmermann, Jens, rev. ed. (Cambridge: Cambridge University Press, 2012), 41.

${ }^{50}$ See Pacem in Terris, §11.

${ }^{51}$ Thomas Aquinas, Summa Theologiae, II-II, q. 26, a. 8, c and ad 1.

${ }^{52}$ Scholars tend to put these passages in a broader context, which includes statements from Jesus condemning those who would ignore all obligations to family members, to assert that the central message is a rejection of the absolutization of kinship ties rather a dismissal of those ties altogether. Barton, Stephen C., Discipleship and Family Ties in Mark and Matthew (Cambridge: Cambridge University Press, 1994), 169-70; Rubio, Julie Hanlon, A Christian Theology of Marriage and Family (New York: Paulist Press, 2003), 49-54.

${ }^{53}$ See Evangelium Vitae, §§58-63.

${ }^{54}$ Pontifical Academy for Life, Moral Reflections on Vaccines; for an updated listing, see "USA and Canada Aborted Fetal Cell Line Products and Ethical Alternatives," Children of God for Life, last modified October 2017, https://cogforlife.org/wp-content/uploads/vaccineListOrigFormat.pdf.

55 Pontifical Academy for Life, Moral Reflections on Vaccines.

${ }^{56}$ Gaudium et Spes, §26, in Tanner, Decrees of the Ecumenical Councils, 2:1084.

${ }^{57}$ Massaro, Living Justice, 84.

${ }^{58}$ Ibid., 85-86; see Hollenbach, David, The Common Good and Christian Ethics (Cambridge: Cambridge University Press, 2002), 11-12, 195-200.

${ }^{59}$ Scheid, Daniel P., The Cosmic Common Good: Religious Grounds for Ecological Ethics (Oxford: Oxford University Press, 2016), esp. 15-44; see also Pope Francis, On Care for Our Common Home (Laudato Si'), May 24, 2015, §§23, 156, http://w2.vatican.va/content/francesco/en/encyclicals/documents/papafrancesco 20150524 enciclica-laudato-si.html; Pope John Paul II, "Peace with God the Creator, Peace with All Creation" (Message of His Holiness John Paul II for the Celebration of the World Day of Peace 1 January 1990), December 8, 1989, §15, https://w2.vatican.va/content/iohn-paulii/en/messages/peace/documents/hf ip-ii mes 19891208 xxiii-world-day-for-peace.html.

${ }^{60}$ Hollenbach, The Common Good and Christian Ethics, 18.

${ }^{61}$ See Kant, Groundwork of the Metaphysics of Morals, 17-18.

62 Massaro, Living Justice, 86. 
${ }^{63}$ One exception might be an accident at one of Merck's vaccine production sites that leaked a significant amount of a toxic preservative into the watershed near Philadelphia in 2006. This is not an indication of the normal risk of vaccines, however. Gregory Roumeliotis, "Blunder at Merck's Biggest Production Site Pollutes Creek," Biopharma-Reporter, last modified July 19, 2008, https://www.biopharmareporter.com/Article/2006/07/06/Blunder-at-Merck-s-biggest-production-site-pollutes-creek.

${ }^{64}$ Martinez, Jose Luis, "Environmental Pollution by Antibiotics and Antibiotic Resistance Determinants," Environmental Pollution 157, no. 11 (Nov. 2009): 2893-2902; Singer, Randall S., "Antibiotic Resistance-The Interplay between Antibiotic Use in Animals and Human Beings," Lancet Infectious Diseases 3 (Jan. 2003): 47-48.

${ }^{65}$ Pontifical Council for Justice and Peace, Compendium, §162.

${ }^{66}$ Pope Pius XI, On the Reconstruction of the Social Order (Quadragesimo Anno), May 15, 1931, $\S 80$, http://w2.vatican.va/content/pius-xi/en/encyclicals/documents/hf pxi enc 19310515 quadragesimo-anno.html.

${ }^{67}$ Pope Benedict XVI, On Integral Human Development (Caritas in Veritate), June 29, 2009, $\S 57$, http://w2.vatican.va/content/benedict-xvi/en/encyclicals/documents/hf benxvi enc 20090629 caritas-in-veritate.html.

${ }^{68}$ See USCCB, "Seven Themes"; Massaro, Living Justice, 87-89.

${ }^{69}$ Centesimus Annus, $§ 13$. Indeed, the Second Vatican Council proclaimed the family "the first and vital cell of society' ("prima et vitalis cellula societas"). Second Vatican Council, Decree on the Apostolate of the Laity (Apostolicam Actuositatem) §11, in Tanner, Decrees of the Ecumenical Councils, 2:989.

${ }^{70}$ Gaudium et Spes, §17, in Tanner, Decrees of the Ecumenical Councils, 2:1078.

${ }^{71}$ Pope John Paul II, The Splendor of Truth (Veritatis Splendor), §§35-45, August 6, 1993, http://w2.vatican.va/content/john-paul-ii/en/encyclicals/documents/hf jpii enc 06081993 veritatis-splendor.html.

${ }^{72}$ Caritas in Veritate, §43. This idea is also treated as its own separate principle or theme, but it has a close affiliation with the principle of subsidiarity because one of the basic rights used to illustrate this point is the right to private property, a social institution that the principle of subsidiarity explicitly seeks to defend. USCCB, "Seven Themes"; Massaro, Living Justice, 92-95; see Pope John XXIII, Encyclical, Mater et Magistra, May 15, 1961, §117, http://w2.vatican.va/content/johnxxiii/en/encyclicals/documents/hf j-xxiii enc 15051961 mater.html.

${ }^{73}$ Centesimus Annus, §51.

74 Pontifical Council for Justice and Peace, Compendium, §193; Bilgrien, Marie Vianney, Solidarity: A Principle, an Attitude, a Duty? Or the Virtue for an Interdependent World? (New York: Peter Lang, 1999), 1.

75 Pope John Paul II, On Social Concern (Sollicitudo Rei Socialis), December 30, 1987, $\S 38$, http://w2.vatican.va/content/john-paul-ii/en/encyclicals/documents/hf jpii enc 30121987 sollicitudo-rei-socialis.html.

${ }^{76}$ This is best seen in the identification of solidarity as the cure for the problem of structural sin. Sollicitudo Rei Socialis, §40; see also Daly, Daniel J., "Structures of Virtue and Vice," New Blackfriars 92, no. 1039 (May 2011): 341-57, at 348. 
77 The preferential option for the poor is sometimes identified as a distinct principle of Catholic social teaching, but concern for the poor is also highlighted as a central component of the principle of solidarity as well, so there is a natural affinity between the two. USCCB, "Seven Themes"; Massaro, Living Justice, 113-16; Byron, "Ten Building Blocks," 5-6; cf. Sollicitudo Rei Socialis, §§39, 45, 46.

${ }^{78}$ Sobrino, Jon, "Bearing with One Another in Faith," in Sobrino, Jon and Pico, Juan Hernández, Theology of Christian Solidarity, trans. Berryman, Phillip (Maryknoll, NY: Orbis Books, 1985), 5-6.

${ }^{79} \mathrm{lbid} ., 37$; Juan Hernández Pico, "Solidarity with the Poor and the Unity of the Church," in Sobrino and Pico, Theology of Christian Solidarity, 87-88.

${ }^{80}$ There are also risks for those who have been vaccinated, as vaccine immunity is not typically 100 percent effective in 100 percent of the people who receive a given vaccine. The risks of contracting the disease after vaccination, however, are lower.

${ }^{81}$ Berezin, Mabel and Eads, Alicia, "Risk Is for the Rich? Childhood Vaccination Resistance and a Culture of Health," Social Science and Medicine 165 (September 2016): 233-45; Smith, Philip J., Chu, Susan Y., and Barker, Lawrence E., "Children Who Have Received No Vaccines: Who Are They and Where Do They Live?," Pediatrics 187, no. 1 (January 2004): 187-95; Reich, Jennifer A., "Neoliberal Mothering and Vaccine Refusal: Imagined Gated Communities and the Privilege of Choice," Gender and Society 28, no. 5 (October 2014): 679-704, at 680; Carrel, Margaret and Bitterman, Patrick, "Personal Belief Exemptions to Vaccinations in California: A Spatial Analysis," Pediatrics 136, no. 1 (July 2015): 80-88, at 86.

${ }^{82}$ Berezin and Eads, "Risk Is for the Rich?," 240.

${ }^{83}$ Pontifical Council for Justice and Peace, Compendium, $\$ 193$ (emphasis in the original).

${ }^{84}$ Centers for Disease Control and Prevention, "State School Immunization Requirements and Vaccine Exemption Laws," last modified February 2017, https://www.cdc.gov/phlp/docs/schoolvaccinations.pdf.

${ }^{85}$ Walter Orenstein, the former head of the Centers for Disease Control and Prevention's National Immunization Program, has argued that "in some places, it's ... easier to get an exemption than to get your child vaccinated." Quoted in Offit, Deadly Choices, 196.

${ }^{86}$ The principle of subsidiarity developed in response to the totalitarian centralization of government in some European countries between the First and Second World Wars, proposing a form of restraint on these governments' overreach into people's lives. Massaro, Living Justice, 90-91.

${ }^{87}$ Caritas in Veritate, $\S 58$ (emphasis in the original).

${ }^{88}$ Gerald J. Beyer, "What Ryan Missed," America, last modified June 4, 2012, http://americamagazine.org/issue/5143/100/what-ryan-missed.

${ }^{89}$ See again Pontifical Academy for Life, Moral Reflections on Vaccines.

${ }^{90}$ Wang, Eileen, Clymer, Jessica, Davis-Hayes, Cecilia, and Buttenheim, Alison, "Nonmedical Exemptions from School Immunization Requirements: A Systemic Review," American Journal of Public Health 104, no. 11 (November 2014): e62-e84.

${ }^{91} \mathrm{~A}$ good example of this distinction can be found in Delaware's compulsory vaccination laws, which permit religious exemptions but require parents to sign a legally binding document affirming that the belief "is 
not a political, sociological, or philosophical view of a merely personal moral code." 14 Del. C. $\S 131(a)(6)$, quoted in Centers for Disease Control and Prevention, "State School Immunization Requirements."

${ }^{92}$ See United States Conference of Catholic Bishops, Forming Consciences for Faithful Citizenship (Washington, DC: United States Conference of Catholic Bishops, 2015), §33.

${ }^{93}$ One version of the precautionary principle is stated as follows: "Activities that present an uncertain potential for significant harm should be prohibited unless the proponent of the activity shows that it presents no appreciable risk of harm." Kelly, Kevin, What Technology Wants (New York: Penguin Books, 2010), 247; see also 246-51 more generally. 